Revista Letras,

Curitiba, n. 94 jun./dez. 2016. ISSN 2236-0999

\title{
Flertes com a História e com a Ficção: as Verdades do Carnaval segundo Rubem Braga
}

\author{
Flirts with history and fiction: the truths of carnival \\ according to Rubem Braga
}

Luiz Carlos Santos Simon *

Resumo:

A proposta do artigo é estudar a multiplicidade das relações entre a crônica, a história e a ficção. Uma das etapas do artigo é considerar algumas contribuições teóricas, escolhidas no debate sobre o gênero, abordadas para revelar as particularidades com as quais a crônica pode se mover ao explorar tais questões. Há apontamentos sobre os escritos de cronistas brasileiros do século XX e suas articulações com a história e com a ficção. Entre eles, sobressai a figura de Rubem Braga, autor das crônicas "Os carnavais de antigamente" e "A moça do carnaval", publicadas no mesmo livro nos anos 1960 e analisadas no texto. O foco sobre o carnaval deve-se ao potencial dessas celebrações como uma temática rica para estimular conexões peculiares da crônica com a história e com a ficção, como a releitura da noção de verdade.

Palavras-chave: crônica; história; ficção; carnaval; Rubem Braga

ABSTRACT:

The purpose of this article is to study the multiple relations between chronicle, history and fiction. One of its stages is a consideration of theoretical contributions chosen in the debate upon genre, approached in order to reveal the particularities in which the chronicle can move while exploiting these issues. Some remarks are developed on the writings of Brazilian chroniclers of the twentieth century and their articulations with history and fiction. Among them, Rubem Braga, author of the chronicles "The carnivals of the old days" and "The young woman of the carnival", published in the same book in the 1960's and analyzed in the text. The focus on carnival is justified by the idea that these celebrations can trigger discussions concerning peculiar connections between chronicles, history and fiction, such as a review of the notion of truth.

Keywords: chronicle; history; fiction; carnival; Rubem Braga

${ }^{\star}$ UEL 
Simon, L. C. S.

Flertes com

a História e

com a Fiç̧ão:

as Verdades

do Carnaval segundo

Rubem Braga entre as práticas do historiador e do cronista, tendo como referências predominantes o século XIX: "Ao contrário do historiador, supostamente superior e desinteressado, ao cronista caberia interagir com as coisas de seu mundo, meter-se onde não era chamado para transformar o que via e vivia." (CHAlHoub; NeVES; Pereira, 2005, p. 12). Ainda que breve, a avaliação dos autores constitui contribuição significativa para o que se pretende abordar aqui. Se a perspectiva do livro, de seus organizadores e dos colaboradores é historiográfica - e isso não coincide integralmente com o propósito de ter como foco central a investigação dos procedimentos literários no objeto eleito para este estudo -, vale observar que esse mesmo objeto se oferece como material rico para pesquisas em diferentes áreas do conhecimento. O livro em questão é um bom exemplo disso: são quase duas dezenas de artigos produzidos por estudiosos que se detêm sobre crônicas de autores brasileiros, interpretando-as como capítulos de história social da vida no Brasil. Assim, se a visão presente no trecho transcrito se concentra sobre um confronto entre o historiador e o cronista, é de se esperar que, nos estudos ali dispostos, sejam desenvolvidas pesquisas que explorem as contribuiç̧ões das crônicas para as reflexões historiográficas. Ao mesmo tempo em que 
Simon, L. C. S.

Flertes com

a História e

com a Fiç̧ão:

as Verdades

do Carnaval segundo

Rubem Braga

esses exemplos proporcionam a constatação de um viés das relações entre crônica e história - o olhar de um pesquisador contemporâneo, em retrospectiva, para textos escritos em séculos anteriores -, o material produzido pelos cronistas pode ser e é suficientemente diversificado para abordar situações e acontecimentos que permitem enfoques igualmente variados quanto à vida social, hábitos e costumes veiculados pelos textos. As relações da crônica com a história são, assim, tão plurais quanto as orientações do próprio fazer historiográfico, pois contribui para esta multiplicidade a liberdade do cronista para não se restringir ao presente e trazer para seu texto registros de recordações. Ao retomar o passado por meio de lembranças, o cronista se apropria do tempo de uma forma particular e exercita a capacidade de rever experiências, o que ainda impulsiona o diálogo entre diferentes temporalidades e dinamiza as perspectivas para fatos e situações em foco.

A ideia de interação com a vida ao redor, incluída no trecho, aponta ainda para uma relação peculiar entre o cronista, o mundo observado e o texto produzido. Se a contemplação do mundo é uma prerrogativa de qualquer ser humano, à disposição, obviamente, também dos historiadores, o modo de se relacionar com as cenas presenciadas e a transposição da percepção destas cenas para textos propiciam posicionamentos diversos de acordo com as inclinações do espectador. Em contraste com os supostos desinteresse e superioridade do historiador, entra em evidência a subjetividade do autor de textos literários, livre para pôr em circulação os recursos ficcionais que vão coexistir com a apreensão e com a exibição da realidade. Tais estratégias representam, para romancistas, contistas, poetas, dramaturgos e cronistas, uma licença, uma forma de reinterpretar fatos, em consonância com o estatuto literário e sem maiores compromissos com a fidedignidade dos acontecimentos. No que diz respeito à figura do cronista, essa licença torna ainda menos nítidas as fronteiras entre real e ficcional. São os formatos variados de crônicas que favorecem a mobilidade do gênero quanto ao aproveitamento da ficcionalização. Se está à disposição do cronista ora narrar ora comentar, deixa de ser tão evidente quando ele é fiel à cena e quando - ou o quanto - ele "inventa". O deslizamento desse pacto se impõe como um desafio para o leitor e para o estudioso.

A proposta deste texto envolve examinar algumas das contribuições de autores que já se dedicaram a pesquisar a crônica no que se refere a estas relações instáveis do gênero com a história e com a ficção. A ideia é avaliar, a partir da articulação com determinados postulados teóricos e críticos, como a subjetividade interfere nos encontros da crônica com tais questões. A seleção de textos de Rubem Braga para a análise deve-se à força do autor como representante do gênero e à relevância de seu estilo no cenário literário. Além disso, a seleção deliberadamente escapa de exemplos que seriam mais cômodos: crônicas identificadas com estratégias narrativas e ficcionais, como muitas de Sérgio Porto, Fernando Sabino, Moacyr Scliar e Luis Fernando Verissimo; e crônicas que focalizam acontecimentos históricos, como as que estes e muitos outros autores escrevem.

Revista Letras,

Curitiba, n. 94 p. 177-191, jun./ dez. 2016. ISSN 2236-0999 
Simon, L. C. S.

Flertes com

a História e

com a Fiç̧ão:

as Verdades

do Carnaval segundo

Rubem Braga

\section{Crônica e história}

Em sua proposta de mapear a trajetória da crônica no Brasil, fornecer informações sobre sua origem e chegar até o estágio ocupado pelo gênero no século xx, Afrânio Coutinho investiga o sentido do termo "crônica" em várias línguas e ressalta, nelas, sua conexão com "o caráter de relato histórico" (couTINHo, 1986, p. 121). Como o propósito do texto deste historiador da literatura é abranger o percurso da crônica e traçar um panorama, algumas linhas após a detecção da solidez deste sentido no termo em diversas culturas examinadas, uma etapa subsequente dos significados atribuídos a "crônica" também recebe destaque: "Todavia, a partir de certa época, a palavra foi ganhando roupagem semântica diferente." (coutınHo, 1986, p. 121). As circunstâncias das alterações no sentido são mais detalhadas na continuação do texto: a época é identificada como o século xix, e os novos significados são reconhecidos como resultado da aproximação do gênero com a literatura e com o jornalismo.

A alusão ao vínculo com o jornalismo permite e até estimula que se verifique como a crônica é percebida sob a perspectiva de um estudioso mais ligado a essa área do conhecimento e a esse meio profissional. Neste sentido, o jornalista e professor de Comunicação José Marques de Melo assim abre seu texto, também voltado para a avaliação da trajetória do gênero: "A crônica é um gênero do jornalismo contemporâneo, cujas raízes localizam-se na história e na literatura, constituindo suas primeiras expressões escritas.” (Melo, 2002, p. 139) Como se pode perceber, também na perspectiva dos estudos jornalísticos, são lembrados os vínculos da crônica com a história, como raiz daquela espécie de texto, demonstrando que, independentemente do enquadramento sincrônico do gênero realizado por aqueles que pretendem estudá-lo, esses vínculos com a história são indicações da genealogia que não se apagam nem são menosprezadas, mesmo em avaliações recentes. As conexões com a história são ainda fortalecidas pela origem da palavra "crônica", consentindo que se interprete o recurso do deslocamento no tempo e da recuperação de experiências do passado como uma estratégia à disposição de cronistas de qualquer época.

O professor e crítico Davi Arrigucci Júnior, no ensaio "Fragmentos sobre a crônica”, também reserva espaço para as origens da crônica e sua vinculação com a história como aspecto significativo para o desenvolvimento do gênero. Como seu interesse recai predominantemente sobre as práticas literárias do século xx - embora o ensaio seja também um panorama sobre o gênero, o livro que o abriga contém textos sobre autores como Manuel Bandeira, Murilo Rubião e Fernando Gabeira, além de um artigo sobre Rubem Braga -, já na segunda página do texto, suas considerações são redirecionadas: "Hoje, porém, quando se fala em crônica, logo se pensa num gênero muito diferente da crônica histórica." (ARRIGUCCI JR., 1987, p. 52). O reconhecimento de um desvio da crônica em relação às suas raízes guarda a consciência da incorporação de outros traços, como 
SimON, L. C. S.

Flertes com

a História e

com a Ficção:

as Verdades

do Carnaval segundo

Rubem Braga

a identificação com o cotidiano, a familiaridade com a imprensa e a adequação à vida moderna. Nem mesmo essa constatação de um percurso redefinido é capaz de impedir que o crítico observe a permanência do componente histórico em textos de cronistas do século $\mathrm{xx}$, como exemplifica o trecho a seguir: "Nas crônicas de Carlos Drummond de Andrade, é comum retornar um narrador rigoroso e preciso de fatos históricos que faz lembrar o antigo significado da palavra [...]" (ARRigucCI JR., 1987, p. 54). E Drummond não é um caso isolado, pois ainda são citados Machado de Assis e Manuel Bandeira como cronistas dedicados à reapresentação de fatos históricos. A ligação com a história nestes autores passa, porém, por certos ajustes e adquire novas tonalidades. Sobre o cronista Bandeira, por exemplo, o crítico afirma: "No fundo distante, o histórico e o ficcional se confundem, ao mesmo tempo que uma poesia inesperada espia através dos fatos da memória." (ARRIGUCCI JR., 1987, p. 54). O elemento histórico já não se exibe em estado puro; está acrescido do poético e do ficcional que certamente o redimensionam. Em outra passagem, ainda se referindo a Bandeira, mas já se aproximando o momento de introduzir Rubem Braga no quadro sobre a trajetória da crônica no Brasil, o autor acrescenta: "Através de figuras singulares de seu convívio, o cronista conta agora fragmentos de uma história menor, aquém dos grandes acontecimentos, vivida no dia-a-dia da Cidade Maravilhosa [...]" (ARRIGUCCI JR., 1987, p. 55). Fica claro que esta adesão à história já não representa um mero retorno à crônica do passado ou a sentidos antigos atribuídos às crônicas. A ideia de uma história menor não é, contudo, desprovida de importância. Tais fragmentos passam a ser vistos como um potencial para constituir material literariamente estimulante - como se confirma através da referência a "uma poesia inesperada" - e ao mesmo tempo preservar a condição de "caráter documental" que Chalhoub (BERGamini, 2013, p. 205) vê não só na crônica mas também em textos de outra natureza.

Curiosamente é esta perspectiva dos historiadores, já introduzida pela citação a Chalhoub, que contribui para uma revisão das abordagens literárias sobre a crônica e para o alargamento da análise das relações entre o gênero e a história. Antes de supor que a iniciativa de tomar a crônica, ou qualquer outro texto literário, como portadora de um caráter documental seja uma operação que diminui ou desvaloriza os componentes estéticos de um texto, é necessário considerar que esta ampliação da noção de documento projeta a relevância das especificidades da crônica e de outras produções literárias para um território que já não se limita a nichos críticos. Trata-se, portanto, de uma valorização daquilo que o cronista elege como matéria e procedimentos centrais. As observações da historiadora Margarida de Souza Neves vão nesta direção:

Frequentadores assíduos das crônicas coloniais, os historiadores recentemente descobriram o fascinante universo dos cronistas modernos que, ao contrário de alguns de seus predecessores,

Revista Letras,

Curitiba, n. 94 p. 177-191, jun./ 
Simon, L. C. S.

Flertes com

a História e

com a Fiç̧ão:

as Verdades

do Carnaval segundo

Rubem Braga abdicam de assumir como tarefa primordial o registro pretensamente objetivo do acontecido para abrir espaço ao comentário pessoal, ao olhar subjetivo, à busca do significado do efêmero e do fragmentário, ainda que mantendo paradoxalmente em comum com os cronistas de todos os tempos o desejo de, através da crônica, condensar na letra o tempo vivido. $\mathrm{Na}$ forma como no conteúdo, na seleção que efetua como na linguagem que emprega, a crônica é sempre, e de formas muito distintas, um texto que tematiza o tempo e, simultaneamente, o mimetiza. (NEvES, 1995, p. 17)

O reconhecimento da subjetividade como instrumento do cronista para lidar com as questões relativas ao tempo é um passo que representa a conquista do apreço das leituras dos historiadores. O fascínio com que este apreço se revela é responsável por evidenciar os trânsitos peculiares de cronistas pelas vias da história e da memória, abrindo-se também como uma vertente para os estudos literários. É a inserção da subjetividade, mais recentemente saudada pela autora e por outros historiadores, que se afirma como movimento importante para dinamizar os modos de reinterpretar a história e conjugar passado, presente e futuro.

\section{Crônica e ficção}

As relações entre crônica e ficção são discutidas com certa frequência em textos destinados a uma apresentação ou introdução sobre o gênero. Estas discussões obedecem à necessidade de uma sistematização que organize, em termos teóricos, as afinidades da crônica com outras formas literárias, como o conto, ou outras produções em prosa, e o poema, que situe, ou procure situar, com maior precisão, enfim, o lugar da crônica no terreno da literatura. Os esforços para esta teorização precisam, porém, estar cercados de cuidados. Antonio Candido detecta, num conjunto relativamente pequeno de crônicas - os textos reunidos na coleção Para gostar de ler para a qual ele redigiu uma apresentação -, algumas tendências para o gênero: "Há crônicas que são diálogos [...]. Outras parecem marchar rumo ao conto, à narrativa mais espraiada com certa estrutura de ficção [...], ou parecem anedotas desdobradas [...]. Nalguns casos o cronista se aproxima da exposição poética [...].” (CANDIDo, 1992, p. 21). A variedade de formas utilizadas pela crônica desponta como obstáculo para uma definição precisa do gênero que se caracterize pela unidade. Neste sentido, a referência à ficção representa apenas uma das possibilidades de que dispõem os cronistas. É descartada, portanto, a ideia de uma conexão automática entre crônica e ficção: o fato de um texto ser considerado crônica não lhe assegura o estatuto ficcional.

Marcelo Coelho, com atuação na imprensa e professor de jornalismo, também salienta a pluralidade que atravessa tanto os caminhos da crônica quan-
Revista Letras,

Curitiba, n. 94 p. 177-191, jun./ dez. 2016. ISSN 2236-0999 
SimON, L. C. S.

Flertes com

a História e

com a Fiç̧ão:

as Verdades

do Carnaval segundo

Rubem Braga

to suas tentativas de definição: "[...] a crônica é um texto de ficção, mas pode ser de não-ficção, é lírico, mas também pode ser puramente humorístico, é em prosa, mas pode ser em verso também [...]." (Coelho, 2002, p. 157). Na perspectiva do jornalismo, é reiterada a noção de uma multiplicidade de formatos para a crônica, algo que Afrânio Coutinho prevê após dividi-la em categorias e fazer a ressalva da inviabilidade de "uma separação estanque entre os vários tipos": "É mesmo da própria natureza da crônica a flexibilidade, a mobilidade, a irregularidade.” (coutinho, 1986, p. 133). A multiplicidade é acompanhada, portanto, de uma tendência à mescla dessas categorias, dificultando o isolamento e o reconhecimento das práticas dos cronistas, incluindo-se entre estas práticas aquilo que, em algumas circunstâncias, poderia ser apontado, sem grandes receios, como ficção. A concepção de o ficcional ser um traço facultativo nas crônicas provoca, assim, um impasse: admitir que a crônica pode ou não recorrer à ficção significa desconfiar da nitidez que supostamente separa o ficcional e o real. Na crônica, nem tudo que se entende como ficção é mesmo resultado de um arranjo e um projeto ficcional; assim como aqueles textos julgados como reproduções diretas de experiências reais podem estar carregados de doses de invenção. O cronista exercitase, com liberdade, naquilo que Jorge de Sá interpreta como "recriação do real" (sÁ, 1997, p. 9). O repertório de cenas vistas, ouvidas ou mesmo experimentadas pode ser acrescido de elementos que o cronista extrai de sua própria imaginação. Neste processo, muitas vezes o resultado é um texto informal e aparentemente despretensioso, que mantém os vínculos com a realidade e com o cotidiano, mas embaralha a questão do ficcional. Compreender a crônica sob esta perspectiva equivale a reconhecer suas particularidades e estratégias, além de evitar a ideia de que se está diante de um texto banal.

Cabe pensar em algumas produções do século xx na esfera da crônica para detalhar um pouco mais a questão. Textos como os de Sérgio Porto, sob o pseudônimo de Stanislaw Ponte Preta, acerca de Tia Zulmira, Primo Altamirando e outros familiares, e os de Luis Fernando Verissimo, especialmente em Comédias da vida privada (1995), apresentam-se como narrativas com claro caráter ficcional. Para esses exemplos, empregar termos como "personagens" e "narrador" é atitude natural, ainda que os leitores desses relatos possam, com frequência, estabelecer paralelos daquelas criações com o mundo real. Revestidas ainda de humor, estas crônicas favorecem amplamente a identificação do leitor com aquelas histórias. Já os textos de Moacyr Scliar incluídos em volumes como O imaginário cotidiano (2001) e Histórias que os jornais não contam (2009) têm como ponto de partida notícias e reportagens publicadas na imprensa. Baseado em acontecimentos reais, o cronista cria pequenas histórias, deixando nítida a caracterização ficcional dos escritos, embora haja referências explícitas aos fatos que serviram de mote. De uma geração anterior, Antônio Maria produz para o jornal textos narrativos com caráter policial nos quais insere uma primeira pessoa que é um repórter. É disponível, inclusive por meio de biografia recente-

Revista Letras,

Curitiba, n. 94 p. 177-191, jun./ dez. 2016. ISSN 2236-0999 
Simon, L. C. S.

Flertes com

a História e

com a Fiç̧ão:

as Verdades

do Carnaval segundo

Rubem Braga

mente publicada por Joaquim Ferreira dos Santos (2006), a informação de que o autor trabalhou como jornalista na área policial. As narrativas em questão não são exatamente notícias, embora possuam sua parcela informativa. Ao mesmo tempo, lê-las como ficções soa como um equívoco, em que pese a subjetividade entranhada no texto.

Os exemplos dos autores revelam a variação com que o ficcional se relaciona com as crônicas. Espera-se que o foco dirigido para a produção de Rubem Braga contribua para uma reflexão mais aguda sobre as complexas interações entre a crônica e o universo da ficção.

\section{Rubem Braga}

Selecionar crônicas de Rubem Braga que componham um diálogo com a história e com a ficção é um passo que pode ser dado com segurança através da opção pelos escritos do autor em sua atuação como correspondente da Segunda Guerra Mundial. Raquel Illescas Bueno ressalta o ponto de contato desses textos com um dos tópicos da questão: "O livro Crônicas da guerra: com a FEB na Itália tem relevância histórica, por trazer a notícia e a reflexão no calor da hora, quando o balanço de perdas e danos da maior guerra de todos os tempos apenas começava a ser feito." (BuENo, 2011, p. 146). Se o vínculo com a história é inequívoco e relevante pelo imediatismo dos registros de um grande acontecimento, pode-se invocar a correlação com o caráter ficcional a partir do emprego do termo "reflexão", que abre espaço para a adição da subjetividade aos relatos, livrando-os de uma narrativa impessoal apegada exclusivamente aos lances das batalhas.

Como já foi apontado aqui, nem só de grandes acontecimentos vive o trânsito da crônica pela história. O professor Wilberth Salgueiro (2014, p. 237) adverte: "Um traço recorrente nas crônicas de Braga é o resgate, ou recordação, de figuras desconhecidas, do povo, anônimas ou esquecidas pela história [...]”.

Em 1967, Rubem Braga inclui no livro A traição das elegantes duas crônicas sobre o carnaval, separadas por pouco mais de vinte páginas: "Os carnavais de antigamente" e "A moça do carnaval”, em que essas figuras desconhecidas ganham relevo. Como o título da primeira sugere, há ali recordações de festas carnavalescas de outros momentos que não se restringem à avaliação dos foliões na década da redação e da publicação das crônicas, como faz a segunda. No primeiro texto, as lembranças conduzem o cronista às experiências da infância e da adolescência, o que permite estimarmos as cenas rememoradas em torno dos anos 1920 e início dos 1930, uma vez que inexiste registro preciso de datas. Esta imprecisão, aliás, somada à subjetividade com que o cronista reconstrói passagens de outros tempos, mescladas, por sua vez, com a atitude de comentar desempenhos das pessoas que celebram o carnaval, são também os aspectos que introduzem o diálogo entre os textos e a esfera ficcional. Para nossa abordagem

Revista Letras,

Curitiba, n. 94 p. 177-191, jun./ dez. 2016. ISSN 2236-0999 
Simon, L. C. S.

Flertes com

a História e

com a Ficção:

as Verdades

do Carnaval segundo

Rubem Braga

aqui deste par de crônicas, podemos considerar, portanto, três momentos como referências temporais: as décadas de 1920 e 1930, das comemorações de um menino e adolescente no carnaval, focalizadas na primeira crônica; a década de 1960, quando o autor traz para seus textos as recordações das festas e o momento -objeto da expressão de opiniões e análises sobre o comportamento das pessoas no carnaval; e o presente, em que dirigimos nosso olhar para os textos de Braga. No parágrafo inicial da crônica "Os carnavais de antigamente”, já se encontram marcas que contribuem para esclarecer o processo de rememoração conduzido no texto: "Para responder, há tempos, a uma enquete de jornal, fiz um esforço para apurar minhas primeiras lembranças carnavalescas. [...] Também tenho uma vaga noção de que cheguei a apache, mas não estou muito seguro." (BRAGA, 1998, p. 173). A referência ao esforço que precisa ser feito para reavivar as lembranças, o uso de uma expressão como "vaga noção" e ainda a ressalva de não estar seguro a respeito dos detalhes recordados apontam para a incerteza do processo rememorativo. No exercício do lembrar, algumas coisas se perdem, outras imagens tornam-se esfumaçadas. O que resta para ser registrado são fragmentos, impressões, sem grande compromisso com a fidelidade aos fatos ou com o rigor na reprodução do passado. O cronista aproxima-se, assim, de uma prática ficcional em que a liberdade criativa e a afirmação de um ímpeto subjetivo ganham primazia em detrimento da realidade. Trata-se de um indício de que a inclinação do texto é percorrer outros espaços, como se torna mais claro a partir do trecho a seguir:

O que me encantava, e até hoje me seduz no carnaval, era a transfiguração das pessoas. As pessoas que eu via todo dia em Cachoeiro, sérias, em seus trajes vulgares, de repente viravam piratas, cowboys, esqueletos, cossacos, índios, sultões, mosqueteiros, palhaços, cozinheiros, almirantes. De um certo ponto de vista parece que eu "acreditava" um pouco nas fantasias, isto é, passava a associar aquelas pessoas às fantasias que tinham usado no carnaval, como se essas fantasias fossem a sua verdade secreta. $O$ disfarce era uma revelação, eis o que sentia inconscientemente. (вRAGA, 1998, p. 173-174).

A primeira frase do trecho já é bastante significativa. Mais importante do que a lembrança precisa das fantasias vestidas na infância, o que vale é externar o sentimento desencadeado pelas experiências do carnaval. Nesse momento, o discurso da incerteza e da indefinição, promovido antes por uma memória hesitante, cede lugar à convicção de expressar o fascínio exercido pelas práticas carnavalescas. O encanto suscitado pela transformação das pessoas era tão poderoso que atravessa o tempo: o cronista decide compensar a ausência de detalhes e a memória escassa com a exposição de sensações que já acometiam o menino

Revista Letras,

Curitiba, n. 94 p. 177-191, jun./ dez. 2016. ISSN 2236-0999 
Simon, L. C. S.

Flertes com

a História e

com a Fiç̧ão:

as Verdades

do Carnaval segundo

Rubem Braga

e continuam comovendo o adulto, levando-o a introduzir, na frase, o tempo verbal no presente. Curiosamente este poder atemporal de sedução do carnaval é reconhecido como "a transfiguração das pessoas", um fenômeno que representa o contraste entre os dias da festa - e suas influências sobre os hábitos das pessoas - e a realidade cotidiana dos demais dias do ano. Com este cotidiano, o cronista é implacável: as pessoas são sérias e seus trajes são vulgares (no sentido de comuns, banais, corriqueiros). Identificar, no restante do ano, esta vulgaridade, corresponde, aliás, a evitar a pecha de imoralidade para o carnaval - que seria uma outra forma e outro sentido de vulgaridade, associado a um comportamento grosseiro - e tomar o partido da(s) fantasia(s). O autor prefere, efetivamente, a transfiguração experimentada nos dias de carnaval, a versão da fantasia e ainda preserva, na condição de adulto, sua crença e sua perspectiva de menino, assim como ocorre no universo da ficção. A ideia de que aquelas fantasias equivalem à "verdade secreta" das pessoas é, sem dúvida, uma revisão operada pelo adulto em relação ao período da infância. No entanto, ao prolongar o sentimento de sedução com a transfiguração dos foliões, o adulto também adere ao mundo da fantasia, em sentido mais amplo, inclusive invertendo ou subvertendo a noção de "verdade". Reconhecer, enquanto adulto, que o menino "acreditava" naquelas fantasias e, ao mesmo tempo, admitir a preservação do encanto com a transfiguração operada pelo carnaval significa a adesão a uma verdade redefinida.

A atmosfera do carnaval estende-se também para as recordações da fase da adolescência, com traços relevantes para contextualizar o sentimento de sedução e encanto provocado pela festa.

O cheiro dos lança-perfumes, os confetes, as serpentinas, a música, tudo era transfiguração. Para o adolescente tímido, as mocinhas deixavam de ser intocáveis ao mesmo tempo que ficavam muito mais maravilhosas - ciganas, piratas de coxas nuas, odaliscas, bailarinas, pierretes.

Só no carnaval eu tinha coragem de dançar; ele é a grande festa dos tímidos. Moças que passavam por mim na rua apenas murmurando um "bom-dia", com um rápido olhar - que milagre! - no carnaval sorriam, cantavam para mim, olhos nos olhos, se deliciavam com o jato de meu lança-perfume, deixavam que eu enchesse seus cabelos de confetes, que as prendesse eternamente com voltas de serpentina - e havia momentos de quase êxtase no tumulto das danças. (BRAGA, 1998, p. 174).

A permanência do fascínio com o carnaval na passagem da infância para a adolescência é garantida e reforçada pela participação dos componentes do ritual carnavalesco: confetes, serpentinas, músicas, danças e fantasias contribuem para o êxito da transfiguração num processo que abandona gradativamente a 
Simon, L. C. S.

Flertes com

a História e

com a Ficção:

as Verdades

do Carnaval segundo

Rubem Braga

inocência infantil para assumir ares de erotismo. As danças adquirem um valor simbólico expressivo: além de o rapaz se investir de coragem para dançar, o contato físico com as moças exerce influência decisiva nesta ebulição erótica. A timidez do adolescente deixa de ser um entrave, pois ele próprio é contagiado pela transfiguração que afeta as moças, confiscando-lhes o pudor, a sobriedade e a indiferença. É importante notar que o resultado desta alteração de comportamento não é recebido como vulgaridade; em vez disso, aquelas jovens, reconstruídas pelas fantasias, são saudadas como "maravilhosas". Essa maravilha que passa a caracterizar as moças discretas no cotidiano do restante do ano e o "milagre" dos sorrisos, dos cantos e dos olhares mais significativos e consistentes não são apenas eróticos, mas proporcionam também uma atmosfera de delírio que corresponde ao "êxtase" registrado no texto. É este flerte com o onírico que orienta a "memória" e a crônica de Rubem Braga, constituindo, ao mesmo tempo uma aproximação da esfera ficcional e um depoimento vigoroso sobre os significados e os modos de perceber o carnaval.

Assim como a crônica "Os carnavais de antigamente" se inicia com a alusão à resposta a uma enquete de jornal, logo no começo de "A moça do carnaval”, há referência a uma consulta telefônica feita pela cronista Lila Bôscoli em busca da opinião de Braga sobre o comportamento das mulheres nos bailes carnavalescos. Neste sentido, é interessante encarar os textos como respostas a demandas jornalísticas. Nesta condição, pode-se supor que as crônicas não fossem além de meras exposições informais e despretensiosas de lembranças ou de opiniões. No entanto, percebe-se que, embora usando o mesmo espaço da origem da demanda - as páginas da imprensa -, o cronista transcende a casualidade em "Os carnavais de antigamente", ao aproveitar, com a liberdade disponível ao gênero, uma série de recursos que podem ser entendidos como líricos ou como ficcionais. A crônica consiste, assim, em resposta mais contundente e alargada às inclinações informativas e ao apego à realidade que se manifestava na demanda. Situações semelhantes são previstas já no início de "A moça do carnaval”.

Ao cronista não escapa a expectativa para sua resposta: "Pela maneira de Lila fazer a pergunta percebi que ela esperava que eu 'pichasse' a foliona. Pois respondi com sinceridade: 'adoro'.” (BRAGA, 1998, p. 197). É construído, no princípio da crônica, um contraste entre as opiniões e as expectativas da jornalista e as concepções expressas por Braga: nas visões da primeira, aquelas mulheres expansivas, dançando e cantando, nos bailes, com os braços abertos em cima da mesa, mereciam a crítica ao exibicionismo; do cronista, porém, a foliona tem apoio irrestrito. Não se trata sequer de uma discordância sobre a pertinência do exibicionismo das mulheres nas festas do carnaval: "Exibicionismo [...], há muito no carnaval; mas o que em outras ocasiões é ridículo e de mau gosto, no carnaval fica sendo engraçado e bem." (BRAGA, 1998, p. 197-198). O cronista reconhece que o carnaval enseja, suscita práticas exibicionistas, mas, ao contrário de condenar tais práticas, as exalta, retomando o movimento de libertá-las da pecha de

Revista Letras,

Curitiba, n. 94 p. 177-191, jun./ dez. 2016. ISSN 2236-0999 
Simon, L. C. S.

Flertes com

a História e

com a Ficção:

as Verdades

do Carnaval segundo

Rubem Braga

vulgaridade, assim como em "Os carnavais de antigamente", quando a atribuição de um outro tipo de vulgaridade se dirigia aos trajes do cotidiano no restante do ano e não às fantasias carnavalescas. Em "A moça do carnaval", há a pequena diferença de admitir o exibicionismo e considerá-lo ridículo. De qualquer modo, isso vale apenas para "outras ocasiões"; no carnaval, tais liberdades e expansões têm o trânsito livre. Mais uma vez é reiterada essa simpatia pelo caráter de licença com que o carnaval é visto. Os dias da festa não são como os demais dias do ano. E, nesse contraste, há uma deferência do cronista pelas transformações observadas, como se pode notar a seguir:

Já conheci muita moça bonita, de ar sério e recatado, que passa o ano inteiro cultivando o mito da própria altivez e no carnaval se veste de prata, de escrava ou de havaiana e se esbalda, sorrindo e rebolando para todos, cantando as letras maliciosas, saltando durante horas em volta do salão, em cima da cadeira ou da mesa. (BRAGA, 1998, p. 198).

O cronista redireciona cada vez mais suas considerações para o campo do específico. Das opiniões genéricas sobre as mulheres, no plural, e seus hábitos no carnaval, ele se desloca para a particularização em busca de um determinado modelo de transformação feminina: da seriedade, do recato e do cultivo do mito da altivez para as fantasias, o esbaldar-se, o sorriso e o rebolado. Neste percurso, há uma inequívoca manifestação de apreço e preferência pela espontaneidade e pela autenticidade representadas pelo segundo momento. A seriedade, o recato e a altivez se diluem como padrões reprimidos diante das práticas libertárias que o carnaval proporciona, segundo a interpretação do cronista: "Sim, adoro mulher fantasiada, porque sua beleza ganha uma graça nova, inesperada, uma como que verdade superior, uma completação de sonho." (BRAGA, 1998, p. 198). É esta graça nova que é alcançada com a transformação obtida, sobretudo, pela adição da fantasia, comprovação do ingresso no espírito carnavalesco. Mais uma vez o cronista recorre ao termo "verdade" para acompanhar o discurso do elogio do plano da fantasia. Se, na crônica anterior, a palavra aparecia numa expressão - "verdade secreta" - que correspondia à exaltação daqueles trajes como a principal identidade dos foliões, aqui, em "verdade superior", sobressai efeito bastante similar à comparação explícita entre os vestuários e seus significados e à demonstração igualmente nítida de preferência pela versão da fantasia. Aliás, não faltam, na crônica, termos que indicam o entusiasmo do autor com este território semântico da fantasia: além daqueles já citados, o uso de vocábulos como “imaginação", "esplendor”, “encanto", "magia”, "fascínio", "fervor” e expressões como "misteriosa grandeza humana" e "noites acesas de fevereiro" (BRAGA, 1998, p. 198-199) compõe a estratégia da defesa do carnaval e do universo da fantasia dentro do qual a mulher ocupa lugar especial. $\mathrm{Na}$ defesa empreendida pelo cro-

Revista Letras,

Curitiba, n. 94 p. 177-191, jun./ 
Simon, L. C. S.

Flertes com

a História e

com a Ficção:

as Verdades

do Carnaval segundo

Rubem Braga nista, as práticas, especialmente as femininas, são reinterpretadas:

Impossível negar o que há de sensualismo e de malícia em um baile de carnaval; mas exatamente nas grandes folionas é que essa malícia e esse sensualismo atingem um grau de gratuidade e de pureza, se desligam do prazer individual para ser uma integração na música e na alegria de todos; ela não tem par, ou não dá ao par nenhuma importância especial, ela goza o prazer de todos e de si mesma, ela se entrega ao ritmo com uma espécie de devoção. (BRAGA, 1998, p. 198).

Ao redimensionar o sensualismo e a malícia como manifestações da pureza, o autor reforça sua perspectiva muito particular das formas de ler o carnaval. A ideia é sustentar que o erotismo que emana das imagens femininas na festa conviva com uma atmosfera sagrada - evidenciada em termos como "pureza" e "devoção" -, sem que esse convívio seja perturbado por alegações de imoralidade. Assim, o prazer que não se vincula a um par específico deixa de ser vulgar e é alçado à condição de expressão máxima de uma alegria autêntica e ímpar. Esta leitura peculiar dos comportamentos carnavalescos avança para a conclusão da crônica em que a moça do carnaval adquire um perfil tipicamente ficcional - e por que não dizer, épico: ela é louvada como "princesa de lantejoulas imortais, guerreira de joelhos incessantes” (BRAGA, 1998, p. 199). A moça, sob suspeita levantada pela jornalista no início do texto, chega, assim, ao término da crônica, ao clímax. Por intermédio da defesa empolgada do cronista, ela se torna uma personagem especial, uma brava heroína.

\section{No fim, o carnaval(?)}

O pesquisador Eduardo Granja Coutinho, em seu estudo acerca dos cronistas carnavalescos brasileiros da Primeira República, faz a seguinte afirmação:

Diz-se, e com certa razão, que Momo morreu. O Carnaval carioca já não desperta a paixão popular como no passado. O riso, a paródia e o espírito irreverente perderam a centralidade na festa e quase já não estão presentes em sua cobertura midiática - tão preocupada com o luxo e o erotismo estereotipado do espetáculo. (CoutinHo, 2006, p. 23).

É difícil verificar se, dez anos após a publicação do trabalho, a avaliação se mantém apropriada e em sintonia com os significados das celebrações contemporâneas do carnaval.

O tempo coberto pela pesquisa desenvolvida - fins do século xix e iní- 
SimON, L. C. S.

Flertes com

a História e

com a Fiç̧ão:

as Verdades

do Carnaval segundo

Rubem Braga

cio do $\mathrm{xx}$ - com certeza guarda certas particularidades que o século xxi já não preserva mais. Além disso, é necessário reconhecer mesmo a força e o foco da mídia sobre um modelo padronizado de carnaval repleto de estereótipos, como tantas vezes deixam transparecer as repetitivas transmissões, para a televisão, dos desfiles das escolas de samba. Por outro lado, há que se considerar o fenômeno relativamente recente do ressurgimento e do incremento dos blocos carnavalescos e do carnaval de rua que, sem grandes aparatos espetaculares, atraem um público cada vez maior como demonstrações de vigor de formas mais populares e autênticas de celebrar o carnaval. Não seriam estas manifestações um formato mais próximo das festas representadas pelos cronistas carnavalescos de outrora e dos carnavais de Rubem Braga? De qualquer modo, Coutinho detecta na sociedade brasileira um processo que, desde o final do século XIX, tenta sufocar o potencial subversivo "latente nessas formas de folia, de maneira a integrá-las à visão de mundo oficial, reinterpretando os seus signos e descartando toda tendência rebelde, explosiva, incontrolável.” (coutinho, 2006, p. 25). É este poder subversivo que se pode tentar localizar nas crônicas de Rubem Braga aqui selecionadas.

As duas crônicas de Braga vieram a público nos conturbados anos 1960. O contexto político, marcado pelo golpe, pela ditadura e pela repressão, tinha como contraponto as reações no âmbito da contracultura. A defesa enfática da liberdade construída por Braga representa uma adesão a este espírito de afastamento das normas, de desligamento de uma realidade opaca, de uma sobriedade padronizada. Neste sentido, os comportamentos das mulheres saudados nas crônicas ostentam um traço de rebeldia que se firma como resposta à repressão. $\mathrm{Na}$ ampliação temporal dessas considerações sobre o carnaval - com a inclusão das lembranças da infância e da adolescência nos anos 1920 e 1930 -, o efeito obtido é o fortalecimento da ideia de que a alegria exibida nas festas do carnaval corresponde a um estado de ânimo mais autenticamente brasileiro. Se hoje pode haver algum estranhamento quanto à reticência de Braga para condenar o exibicionismo, é preciso considerá-lo com significados particulares naquele contexto. A interpretação do autor para as verdades trazidas à tona pelo carnaval consiste, enfim, na exaltação de valores que devem ser considerados relevantes como material de revisão da história e, ao mesmo tempo, na consolidação das afinidades com o universo ficcional, através do elogio da fantasia e do fazer literário como instrumentos poderosos para enfrentar a realidade. 
Simon, L. C. S.

Flertes com

a História e

com a Fiç̧ão:

as Verdades

do Carnaval segundo

Rubem Braga

\section{Referências}

ARRIGUCCI JR., D. Enigma e comentário. São Paulo: Companhia das Letras, 1987.

BERGAMINI, A. Entrevista com Sidney Chalhoub. Organon: Revista do Instituto de Letras da Universidade Federal do Rio Grande do Sul, Porto Alegre, v. 28, n. 55, p. 203-218, jul.-dez.2013.

BRAGA, R. A traição das elegantes. 4. ed. Rio de Janeiro: Record, 1998.

BUENO, R. I. A crônica entre o tudo e o nada. In: TOLLENDAL, E. J.; AZEVEDO L. Relendo a teoria. Uberlândia: EDUFU, 2011.

CANDIDO, A. A vida ao rés-do-chão. IN: CANDIDO, A. et. al. A crônica: o gênero, sua fixação e suas transformações no Brasil. Campinas: Ed. da Unicamp; Rio de Janeiro: Fundação Casa de Rui Barbosa, 1992.

CHAlHOUB, S.; NEVES, M. de S.; PEREIRA, L. A. F. Apresentação. In: - (Orgs.). História em cousas miúdas: capítulos de história social da crônica no Brasil. Campinas: Ed. da Unicamp, 2005.

COELHO, M. Notícias sobre a crônica. In: CASTRO, G. de; GALENO, A. (Orgs.). Jornalismo e literatura: a sedução da palavra. São Paulo: Escrituras, 2002.

COUTINHO, A. Ensaio e crônica. In: COUTINHO, A. (dir.); COUTINHO, E. (co-dir.). A literatura no Brasil. 3. ed. rev. e aum. Rio de Janeiro: José Olympio; Niterói: Ed. da UFF, 1986. v. 6.

COUTINHO, E. G. Os cronistas de Momo: imprensa e carnaval na Primeira República. Rio de Janeiro: Ed. UFRJ, 2006.

MELO, J. M. de. A crônica. In: CASTRO, G. de; GALENO, A. (Orgs.). Jornalismo e literatura: a sedução da palavra. São Paulo: Escrituras, 2002.

NEVES, M. de S. História da crônica. Crônica da história. In: RESENDE, B. (Org.). Cronistas do Rio. Rio de Janeiro: José Olympio: CCBB, 1995.

SÁ, J. de. A crônica. 5. ed. São Paulo: Ática, 1997.

SALGUEIRO, W. Crônicas do Espírito Santo de Rubem Braga: escritos melancólicos e bem-humorados sobre o tempo - "Esse bicho que tudo come". In: LOPES, O; SODRÉ, P. R; SALGUEIRO, W. (Orgs.). Recados de tempo: estudos sobre as crônicas de Rubem Braga. Vitória: EDUFES, 2014.

SANTOS, J. F dos. Um homem chamado Maria. Rio de Janeiro: Objetiva, 2006.

SCLIAR, M. O imaginário cotidiano. São Paulo: Global, 2001.

. Histórias que os jornais não contam. Rio de Janeiro: Agir, 2009.

VERISSIMO, L. F. Comédias da vida privada: 101 crônicas escolhidas. 15. ed. Porto Alegre: L\&PM, 1995.

Revista Letras,

Curitiba, n. 94 p. 177-191, jun./ dez. 2016. ISSN 2236-0999
Submetido em 16/9/2016

Aceito em 24/9/2016 